\title{
Bulgarian Defense Reform from 1990-2008 as a Change Management Process and the Role of Integrity Building
}

\section{Velizar Shalamanov *}

\section{Introduction: Reform, Transformation, or Simply Change Management?}

This article is focused on analyzing the process of defense reform in Bulgaria over the last twenty years as a process of change management in a highly dynamic security and development environment, both internally and externally. The goal is to draft lessons from this experience for the development of the Strategic Map and Balanced Score Cards for the integrated security sector as a strategy-focused organization. Integrity building in the defense and security sector is considered to be one of the key initiatives for success. The special role that can be played by Operational Analysis (OA) and Computer Assisted Exercises (CAX) will be emphasized in this essay as providing strong analytical support for the transparency, traceability, and accountability of decision making. ${ }^{1}$ Leadership and political will for good governance are also recognized as other key requirements for effective change management within the security sector. ${ }^{2}$

In order to develop and implement a vision of change, it is sometimes important to select the keywords to be used. These keywords are essential for building and presenting a new security concept. In this context, the experience in Bulgaria could be considered as having evolved around the following key concepts:

- Adaptation to new realities: in the transition as it was experienced in Bulgaria, the processes of adaptation were unable to address fundamental changes in the environment

- Reform considered as a one-step change, primarily in the strength and structure of the armed forces, is not sufficient to effect the transformation of Eastern-model forces to forces that are able to participate in the global defense organizations of the West

- Transformation along anything approaching the lines of the U.S. model is an inadequate goal for implementation in Bulgaria for many reasons, not least because of the gaps in technology and organizational capacity

* Dr. Velizar Shalamanov was Deputy Minister of Defense for Policy, Planning, and Integration in Bulgaria from 1998-2001. He is currently the chairman of the George C. Marshall Association-Bulgaria and the director of the Center of Operational Analysis in the Bulgarian Academy of Sciences. This article is based on a lecture he has presented in the training module "Building Integrity in Defense Establishment," developed by U.K. Defense Academy under the NATO Trust Fund for good governance.

1 See Klaus Niemeyer, Velizar Shalamanov, and Todor Tagarev, "Institutionalizing Operations Analysis for Security and Defense in Bulgaria," Connections: The Quarterly Journal 7:2 (Summer 2008): 45-53.

2 Velizar Shalamanov, "Lessons of Transition in Bulgarian Security and Defense," Information \& Security: An International Journal 5 (2000): 9-19; http://infosec.procon.bg. 
- Viewing Change Management as an extension of the reengineering process helped create a good environment for maintaining the comprehensive approach to the complex process and long-lasting effort of institution building in defense and security. ${ }^{3}$

Just after the radical political changes that took place at the end of 1989 , Bulgaria's main security concept was focused on "adaptation" in order to "preserve" the armed forces and security sector at large as an instrument of stability and non-violent transition. When it became clear in 1991 that serious changes were required in the defense sector, the "reform concept" was introduced; a later compromise was reached, which included only primarily superficial changes. In 1998-99, the Bulgarian MoD, the U.S. DoD, NATO HQ, and consultants from several NATO countries (including the U.K., Netherlands, Germany, and France, as well as Italy and Greece later on) jointly carried out a defense reform study in Bulgaria. As a result of this study, the Bulgarian defense establishment was put on the path of "change management" to become an organization structured around strategy and doctrine. And it was this change in Bulgaria's stance toward defense that led to Bulgaria's invitation to join NATO.

The implementation of a "defense transformation concept" has been attempted several times, primarily at the level of words and papers. These attempts were largely unsuccessful, because they attempted to implement the transformation using a U.S. model in a country that did not possess adequate resources and capabilities. Currently the "change management" concept is being introduced mostly by the research community in the context of building an integrated security sector; evaluating the best way to implement Bulgaria's national resources (including NATO and EU membership); building a strategic partnership with the U.S.; and taking advantage of other new opportunities for increasing the effectiveness and efficiency of Bulgaria's security organizations in the new security environment focused on crisis management. The change management approach to security sector development requires new theoretical models and practices for its implementation.

\section{The Framework of the Defense Establishment in the New Security Environment}

One of the first steps in providing the foundation for the change management concept in Bulgaria's security sector was the development of the general reference architecture of security and the security sector (see Figure 1). Security is related to the required operations with respective operational concepts (e.g., Effect Based Operations, Network Enabled Operations, etc.). Four main pillars support this security concept:

- Documents, from the constitution/founding document through laws and other normative acts to define rules; followed by concepts, strategies, and doctrines

3 Velizar Shalamanov and Todor Tagarev, "Reengineering Defense Planning in Bulgaria," Research Report 9 (Sofia: Institute for International and Security Studies, December 1998); available at www.isis-bg.org/Publications/Shalamanov\&Tagarev_Reengineering_1998-12.htm. 


\section{Architecture Framework for Defense Institution Building}
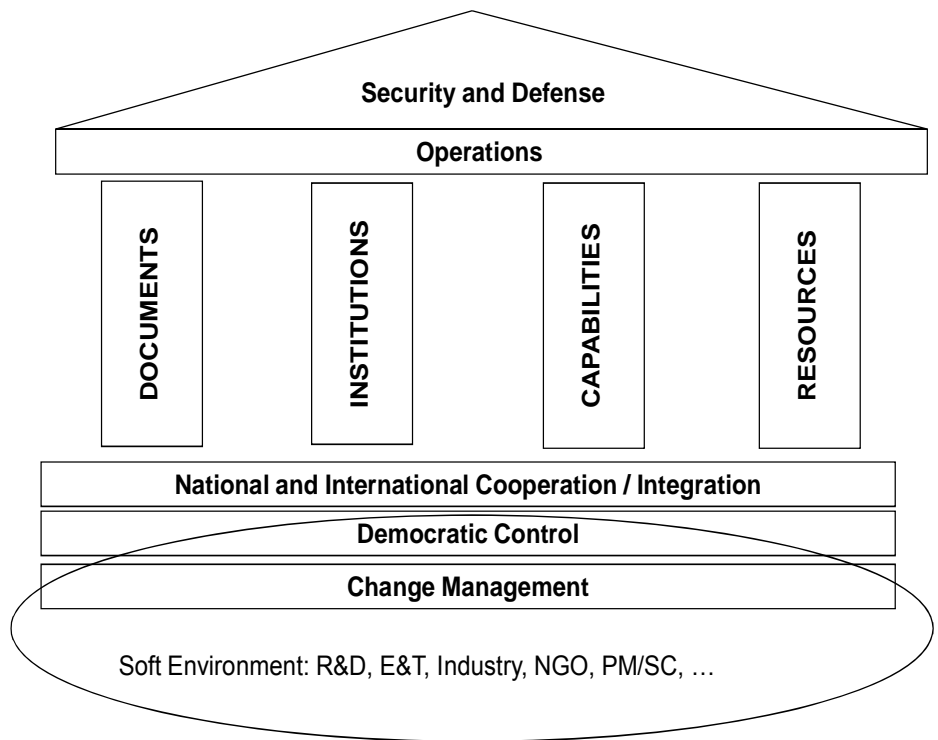

Figure 1: The Architecture of the Security Sector.

to define goals and tools; and reporting/assessment documents, such as annual reports and white papers

- Organizations and institutions, including all types of institutional arrangements on the governance, management, and operational levels

- Systems and capabilities in all the areas required to effectively carry out operations, as defined on the roof of the "temple of security" shown in Figure 1

- Resources, including financial, material, human, information/knowledge, and political and motivational resources.

These pillars in turn rest on three fundamental bases:

- National and international cooperation and integration, to provide horizontal and vertical integration between national elements of the security sector, as well as regional and international cooperation and integration in security alliances such as NATO

- Democratic control over the armed forces, based on political and public support, to provide legitimacy and strength to the security sector in the long term, as well as to prevent the use of the security sector against the public or in any private interest 
- A robust change management capacity, based on the concept of continuous improvement and readiness for radical change if such occurs in the environment.

This framework exists in the larger environment of relations between security and development, threats and opportunities, as well as relations between the security sector and all institutions of civil society with any relationship to national/civil security, including the academic and business sectors.

Based on the requirement to carry out change management within the security sector in the right security and economic environment, as well as in the appropriate strategic context, we use the model of influences and relations as presented in Figure 2.

Bulgaria is in a unique position, both geographically and geo-strategically. It is located in South Eastern Europe (SEE), a region that extends from the Western Balkans to the Caucasus. Thus it sits squarely on the border between the EU and Turkey, and between NATO and Russia. These actors - the EU, the U.S., NATO, Russia, and Turkey - are the key external influences on Bulgaria, but we must also take into account many other key bilateral relations between Bulgaria and individual member states of NATO or the EU, as well as relations between these factors of influence. The country is surrounded by active conflict zones in Europe, Asia, and Africa within a radius of $1000-2000 \mathrm{~km}$. This environment and its dynamics are important factors that serve to drive the processes of defense reform and security sector change management in general.

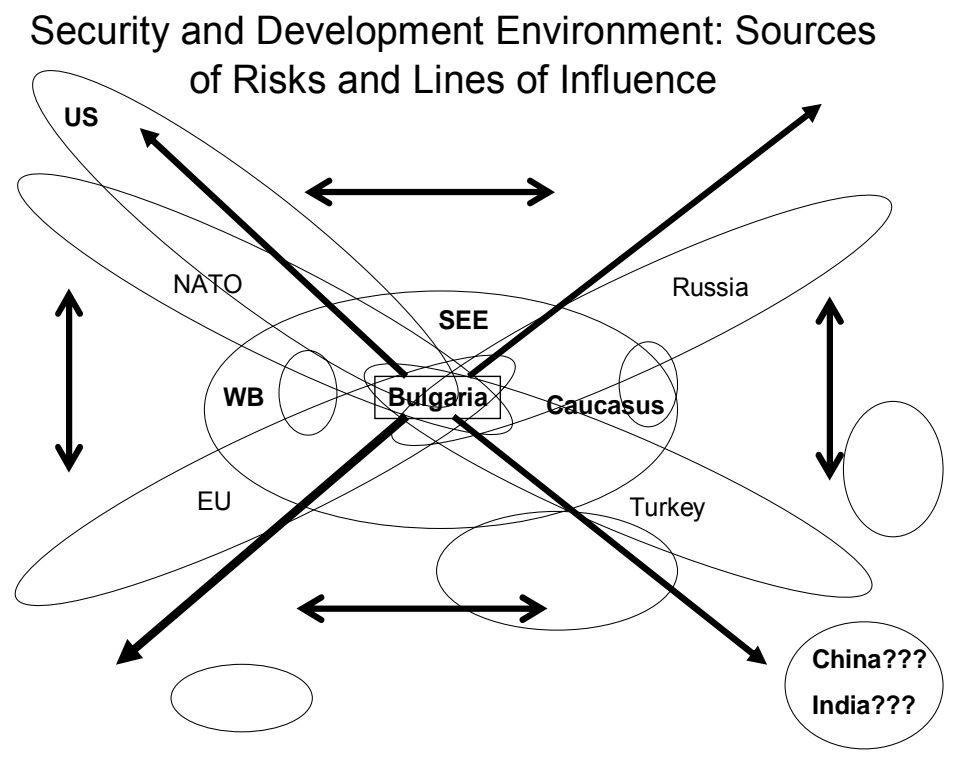

Figure 2: Bulgaria and SEE at the Center of the Great Powers' Interactions. 


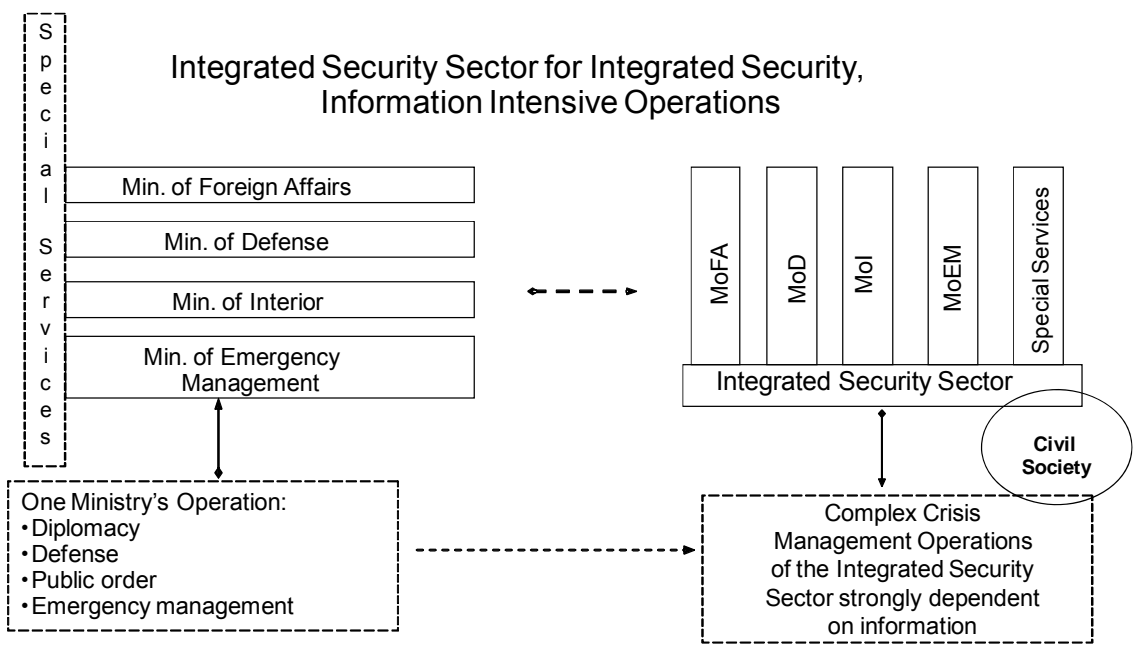

Figure 3: Complex Crisis Management Operations (CMO) and Integrated Security Sector (ISS).

The current structure of the security sector includes different institutions that have a monopoly over the use of force or over information operations in support of the use of force, and thus follows the structure of well-defined and separate operations. At the same time, however, the current security environment requires a comprehensive approach to crisis management, where interagency, international, joint, and private-public cooperation are essential (Figure 3). This factor is driving integration in the security sector, where different institutions maintain their individual identities while possessing the opportunity to form combined interagency joint forces for every specific operation, with changes in the mix of forces at different stages of the operation, or when moving from one operation to another in the same region. ${ }^{4}$

The integrated security sector is not a new organization, but rather a concept for organizing the institutions participating in this network in order to be able to work together and support and reinforce each other, since for every operation one institution

4 Velizar Shalamanov, "Civil Security and Crisis Management: The Concept Development and Experimentation Process in Bulgaria (the Role of the US, NATO, and the EU in SEE)," in The Fight Against Terrorism and Crisis Management in the Western Balkans, ed. Iztok Prezelj (Amsterdam: IOS Press, 2008), 147-164. 


\section{Geo-political context of transformation}

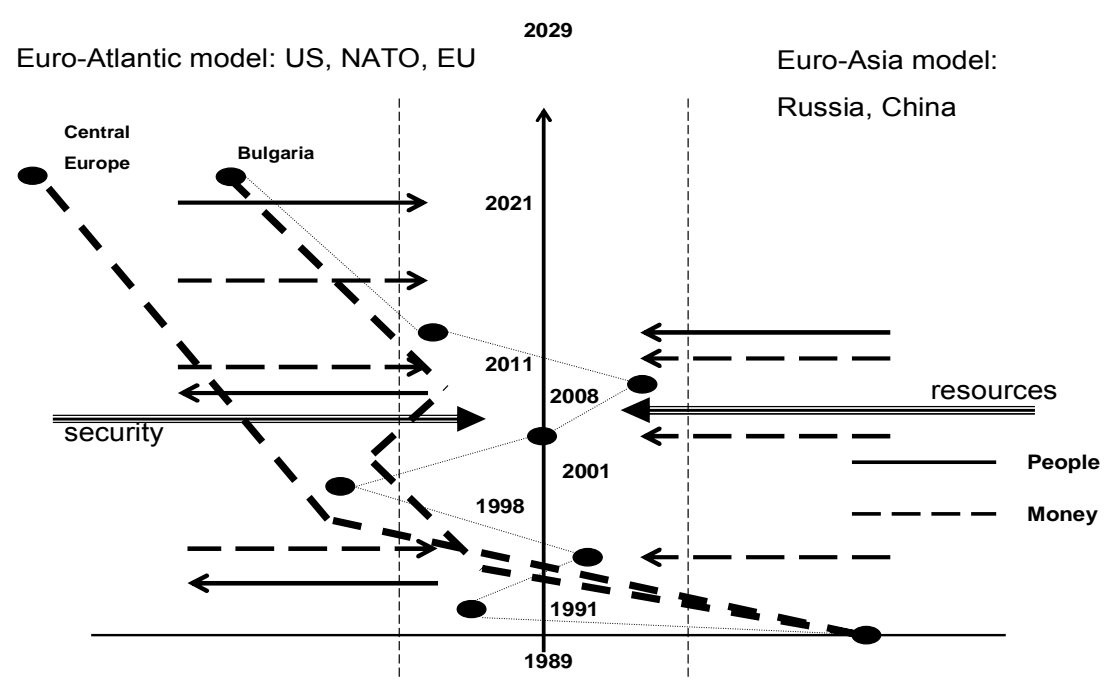

Figure 4: Trajectory of the New Members of NATO/EU in Central Europe and the Oscillations of Bulgarian transition.

will have the leading role (depending on the legal status of the operation). ${ }^{5}$ It has to be stressed that an integrated security sector requires as a precondition a higher level of integrity in every participating institution.

As a result of such an environment and the dynamics of both external factors (flows of money, people, resources, and security guarantees) and internal factors (the political orientation of the majority within the Bulgarian Parliament), Bulgaria has been subjected to a highly interesting trajectory of transition during the last twenty years (see Figure 4). Its situation is unique in comparison with any other new member of NATO or EU during these twenty years, and is more similar to the model of the countries that are now members of PfP, and perhaps to that of other NATO partner countries outside Europe. The internal dynamics of Bulgaria's national "climate" is the key factor in shaping the processes of defense and security sector reform overall.

The key point for the future is that Bulgaria's economy is becoming more and more integrated into Euro-Atlantic frameworks (with the exception of the energy sector and, perhaps the tourism and real estate sectors after the current economic downturn). At

5 Velizar Shalamanov, "Civil-Military and Interagency Cooperation in the Security Sector in Bulgaria," in Security Sector Reform - Does It Work?: Problems of Civil-Military and Interagency Cooperation in the Security Sector, eds. Philipp Fluri and Velizar Shalamanov (Geneva: DCAF-GCMA, 2003), 79-114. 
present, the level of integration in the political and security sectors in Bulgaria is trailing that of the economy, but the situation may reverse itself, and come to resemble the periods from 1991-92 and 1997-2001, when the political and security sectors were in a leading position. The experience of these two periods proved the importance of such an approach in Bulgaria.

\section{Chronology of Changes in the Bulgarian Defense Establishment, 1990- 2008: Problems and Lessons Learned}

Below is a very short list of the key changes in Bulgaria's defense establishment that have taken place in the past twenty years. Not all of them were driven by the same vision, will, and commitment to integration. ${ }^{6}$ But, in general, the steps that were taken in accordance with the Euro-Atlantic model of development shaped the positive trend that brought Bulgaria into NATO and later the EU-steps that were reinforced by Bulgaria's very strong partnership with the United States.

The key cases of the defense reform process in Bulgaria to be analyzed are:

1. Depoliticization of the armed forces, in 1990

2. The Constitution of 1991 and the first civilian Minister of Defense, also in 1991

3. The Defense and Armed Forces Law of 1995

4. The National Security Concept (1998) and Plan 2010 (1998)

5. First Strategic Defense Review (SDR) of 1998-99, and the Military Doctrine of 1999

6. Kosovo Crisis (1999)

7. Situation Center in MoD and Government

8. Failure of the Advanced Defense Research Institute (ADRI)

9. Interoperability center and the National Security and Defense Department in the Defense and Staff College (DSC)

10. Plan 2004 (1999) and the Membership Action Plan (MAP) 2004 (1999)

11. Defense management study and Planning Programming and Budgeting System (PPBS) introduction / Good Governance model

12. C4 Study and introduction of the Chief Information Officer (CIO) institution

13. Defense education and research adaptation

14. Institution building study and failure in introducing the Integrated $\mathrm{MoD}$ in 2000

15. Amendments to the Defense and Armed Forces Law (2000)

16. Crisis in Macedonia, 2000-01

6 Bulgarian Ministry of Defense, Bulgaria's Way: A Book for the Partners - Our Vision, Our Will, Our Faith (Sofia: Ministry of Defense, 1999). 
17. Failure of the Defense Modernization Study, 2001-03

18. Starting the operation in Afghanistan, 2001-02

19. Lack of integration in the Ministry of Defense

20. Failure of the defense modernization plan (2004)

21. Failure of the second SDR and development of Plan 2015

22. Start of operations in Iraq (2003)

23. NATO membership (2004) and continuing influence of the former secret services

24. Elimination of conscription (2007) and shift to a new reserve armed forces model

25. Failure of Plan 2015 and adapted version; development of Plan 2018.

This essay will briefly cover only these cases that could be used as positive examples of integrity-based processes on several levels: political, international, doctrine implementation, and institution building. In addition, we will focus on areas that highlight progress in several key transformation areas, including Command, Control, Communications, Computers, Intelligence, Surveillance, and Reconnaissance (C4ISR), education, and research. There are some other examples of a less positive nature that might also be mentioned in order to draft a fully informed set of lessons learned, in areas such as defense modernization (procurement); defense management and materiel management; participation in operations (Iraq); and elimination of conscription and the development of a reserve corps. The key issue behind all these cases is the quality of the process of change management, leading to the continuous improvement of the governance and management processes based on the concept of integrity building.

\section{Military Doctrine of 1999: An Example of Political Integrity}

In 1997, the Union of Democratic Forces won the national elections in Bulgaria with a clear commitment to bring the country into NATO and the EU. The Union's commitment to this election promise led to the ratification in Parliament of a new national security concept, and a year later a new Military Doctrine that stipulated Bulgaria as a de facto member of NATO and the EU and provided a vision, strategy, and base for implementation planning in this direction. ${ }^{7}$

The newly developed military doctrine provides an even better example of the power of political integrity, because after more that a year of efforts to jump-start real defense reform, which were stymied by attempts by the conservative military leadership to replace it with camouflaged adaptation, the changes in the military and later in the high political officials were made together with a request for help from NATO and the U.S. in order to fulfill the commitments to move the country towards NATO membership. Even more significant was the fact that, for the first time, a document like the

7 Velizar Shalamanov, "Priorities of Bulgarian Defense Policy and Planning," Security Policy 2 (1999): 3-21. 
Military Doctrine was developed through the integrity-building process of expert consultation, political-military cooperation, public discussion, and consultations with civil society. During discussions around the Military Doctrine it became clear that all the arguments used by some conservative members of the military (mostly generals) could not survive in real debate, because of the flaws in their concept. The document was finally approved in the Parliament after serious work with the representatives of all the political parties.

The language of the Military Doctrine was very precise; it even included numbers to provide clear mandate and guidance for the next steps. It is important to mention that the Doctrine was approved in the Parliament during the NATO campaign in Kosovo in 1999. In fact, key aspects of the document were immediately tested, together with the new Crisis Management Concept that was developed in support of the doctrine's implementation.

\section{The Kosovo Crisis of 1999: Integrity on the International Level}

The Kosovo crisis is a good case with which to illustrate the importance and value of integrity as a key principle for success. First of all, the NATO operation in Kosovo was a clear example of integrity in action, and provided a good lesson for the Bulgarian people of what political integrity means on the international level. Second, the same principle of integrity was the key criterion for the decision-making process in the government regarding the conflict, and especially its support for the Kosovo intervention through the Security Council of the Prime Minister and the newly established Temporary Interagency Situation Center.

Our policy was in full compliance with Bulgaria's Security Concept of 1998 and Military Doctrine of 1999, and provided a test case for the key ideas underlying the defense reform plan that was under development in this period. The integrity of this policy with the government's action provided a solid foundation for gaining public support and maintaining all the consultations with NATO and individual member states, as well as when it came to dealing with a request from Russia for permission to fly over Bulgarian territory. More important than all this, however, was the positive lesson that came at the end of 1999, when the EU decided to invite Bulgaria to start negotiations for future membership. This step confirmed in Bulgarian society the importance of integrity-based behavior in critical situations.

\section{Plan 2004 of 1999: Integrity Demonstrated in the Implementation of the}

\section{Doctrine}

The development of the defense reform plan known as "Plan 2004" was quite different from any other reform plan that had been undertaken in Bulgaria to date. First, it was based on the National Security Concept and the Military Doctrine, under clear leadership of the prime minister and with support from the president and Parliament. Second, it was based on a solid operational analysis of many options for the structure, strength, equipment and training, and possible courses of action for the armed forces. Third, the key element of force planning was surrounded with coordinated plans for education and training, intelligence and counterintelligence, medical support, logistics support, 
social support, acquisition and research, transition of functions and structures outside $\mathrm{MoD}$, transforming military formations outside $\mathrm{MoD}$ into civilian organizations, etc. Most of all, the plan was supported by the very clear implementation mechanism and institutions on the $\mathrm{MoD} /$ General Staff level, and by very clear budget projections until 2004.

The idea of Plan 2004 was to cover the period from 1999 to 2004 with a goal of setting forth most of the steps that would need to be taken until 2002 in order to achieve an invitation to join NATO and to finalize (after actualization) the main goals of the plan up to 2004, with a provision for replacing the plan with a long-term one after Bulgaria had received an invitation to join NATO and secured membership in the EU. ${ }^{8}$ In the plan there was still an option for regeneration of the force structure if conditions changed to the level that NATO membership was refused, and the security environment was deteriorating.

Although the visibility of serious downsizing and restructuring led to the plan initially being considered as focused on reducing the size of the force structure, the key element of the plan was its provision for institution building and process improvement through the introduction of a planning, programming, and budgeting system (PPBS). Another crucial aspect of the plan was the incorporation of mechanisms of transparency, accountability, and measurement of results, along with the use of operational analysis in decision making and computer assisted exercises in joint training.

This plan was the first defense plan fully implemented in the period 1999-2004 in Bulgaria, but even more important is the fact that it reached its strategic goals: membership in NATO, and a realignment of the budget, with at least 20 percent for modernization and 10 percent for operations. The plan also prepared the ground for the transition to a fully professional volunteer military in 2007.

The strong commitment of the prime minister, the president, and the chairman of the National Security Committee to this reform process - as well as the minister of defense and his team - ensured high level of integrity in implementation of the National Security Concept, the Military Doctrine, the Defense Reform Plan, and the Membership Action Plan. With this plan the practice of annual reports to the Parliament was established, and the preparation of the first "White Paper on Defense" started.

\section{Defense Management Study and PPBS Introduction: Integrity and Institution Building}

Work on the Military Doctrine and Plan 2004 was supported by the introduction of PPBS and a special study on defense governance and management. There was a study on civil-military relations and parliamentarian control starting in 1998, and after the approval of Plan 2004 a new study was initiated with the U.K. MoD Department for Consultancy and Management Services (DCMS) to further institutionalize the practices

8 Valeri Ratchev, Velizar Shalamanov, and Todor Tagarev, "Reshaping Bulgarian Armed Forces for the 21st Century," in Bulgaria for NATO 2002, ed. Ognyan Minchev, Valeri Ratchev, and Marin Lessenski (Sofia: Institute for Regional and International Studies, 2002), 204-78. 
of good governance and defense management, including changes in the organic statute of the MoD and Bulgaria's Defense Law.

In order to increase transparency, accountability, and the measurability of management processes, the Programming, Integration, and Modernization Councils were established in the MoD (jointly with the General Staff), supported as secretariats by the newly established Defense Planning, Euroatlantic Integration, and Armaments Policy directorates as well as a newly organized J5 in the General Staff (GS) and similar division in the services' headquarters. ${ }^{9}$ In order to run support programs outside the armed forces, some specialized executive agencies were established according to the State Administration Law.

Even now, after ten years, the best sources of information are still the Program Memoranda and Memoranda of Program Decisions prepared by the Programming Council as well as other reports form the Integration and Modernization Councils. In order to build integrity for this process, many officers and civilian experts were trained in Bulgaria as well as abroad in the areas of resource management, transparency, and accountability. Special educational and training modules were introduced in the Defense and Staff College (DSC) and the National Military University (NMU), and a special department on defense management was established in the DSC. Integrity as a value was stressed in these training initiatives.

\section{C4 Study and CIO Introduction: Integrity in Addressing the Critical Areas}

C4ISR was defined as a priority area in the Military Doctrine in order to provide a higher level of interoperability with NATO forces, as well as to promote the modernization of the Bulgarian armed forces and move them forward to being organized along the lines of the information society. To provide integrity in pursuing this priority, a special C4 Study was performed with the United States DoD in 1999-2000. In addition to the standard report, this study produced a special manual for the life-cycle management of C4ISR programs and a C4ISR Strategic Plan. With this manual, the office of the Chief Information Officer (CIO) was introduced in the Bulgarian MoD and proposed as national initiative through the Government Committee on Information Society.

One lesson learned was that, in order to overcome the resistance of the General Staff, we made a compromise to appoint as CIO the chief of J6, and to have a deputy department director from MoD dealing with communications and information systems as deputy CIO. This seriously limited the ability to provide strategic leadership in the area and to use it as a change management tool.

9 Velizar Shalamanov, "Activities and Problems in the Bulgarian Ministry of Defence Concerning NATO Enlargement," in International Workshop on Transparency of Defence Resource's Planning and Budgeting: National and Euroatlantic Dimensions (Sofia: University Publishing Stopanstvo, 2002), 92-102. A key aspect of the transparency of the resource management process was the introduction of a program-based approach. For details see Todor Tagarev, "Introduction to Program-based Defense Resource Management," Connections: The Quarterly Journal 5:1 (Spring-Summer 2006): 55-69. 
The efforts in the C4ISR area led to increasing funding being dedicated to the area, and many positive results were achieved. Financing came both from the national budget and from Foreign Military Financing (FMF) from the U.S., and later from the NATO Security Investment Program (NSIP) as well. In many cases the Bulgarian MoD was a leading ministry in IT governance processes at the government level. Introduction of the CIO institution and the life-cycle management manual was a tool for higher transparency and accountability and provided a higher level of integrity in the decision-making process.

\section{Defense Education and Research Adaptation}

It was clear that these sweeping changes in doctrine, organization, management models, and C4ISR systems would require significant improvements in the area of Education \& Training (E\&T) and Research \& Development (R\&D). In this respect the key focus was on the establishment of a new faculty on National Security and Defense, and on the creation of an Interoperability Center in the Defense and Staff College. Additional efforts included the integration of all service military academies in one National Military University and the fusion of various institutes in an integrated Advance Defense Research Institute. No less important was the step that was taken to integrate these institutions in the PfP Consortium and with civilian E\&T/R\&D institutions, namely universities and the Bulgarian Academy of Sciences. It represented a clear step toward greater integration of knowledge organizations as part of the reform process, which helped lend it greater credibility and integrity. In order to provide stronger leadership, all these institutions were directly under the authority of the Minister of Defense and were established under the decisions of the Parliament and Government. The process of laying down foundations for change was a great success, but all these steps were not fully sufficient to prevent some failures in the next steps, when the pace of integration was slower and focus shifted from defense reform to other priorities with some compromises to the integrity of the process.

\section{Failure of the Defense Modernization Study and Problems in the Modernization Process}

The case of the Defense Modernization Study in the period 2001-03 is one example of how a lack of integrity can ruin efforts and reduce the return on money invested. We were very enthusiastic about conducting a Defense Reform Study (DRS) with the United States and a Defense Management Study with the U.K. (as well as an Air Defense Study with NATO). So Bulgaria applied through a Letter of Request (LoR) for a Defense Modernization Study as being the next important step in the defense change management process. MPRI was selected for this study, and it was totally outsourced by the DoD. This was not the case with the Defense Reform Study and the C4 Study, which were mostly performed or at least led by DoD personnel at very high level and with the full commitment of DoD officials. Secretary Cohen personally presented the results of the DRS to Minister Ananiev, and the results of the C4 Study were presented to me as Deputy Minister by DoD CIO Mr. Money). 
As a result of this situation, the Defense Modernization Study lacked any strong political support from the Bulgarian and U.S. side, and was dominated by the General Staff and the administration. Efforts soon were transferred from the difficult issues of institution building for defense modernization, planning of defense modernization, and establishing a legal framework for the implementation of such plans to some "tactical" trade-off issues and to training.

As a result of this failed effort, we saw that the Ministry of Defense was not ready institutionally to manage the process of modernization, despite the fact that in 2003 we had already achieved a goal for 20 percent and more of the defense budget to be used for the procurement of new equipment. It was not only pure procurement that lacked meaningful support, but other important aspects of change management as well, including such areas as the utilization of extra equipment and property, relations with the Bulgarian defense industry (and especially the MoD-owned defense company TEREM SHC). This environment was not able to encourage integrity for the many critical decisions that needed to be made on training airplanes, transport helicopters, $\mathrm{C} 4$ modules for operations, transport airplanes, transport vehicles, armored personnel carriers and corvettes procurement, as well as the overhaul and upgrade of Mi-24/Mi-17, MiG-29 and Su-25 aircraft, different radars, etc. The result is that more than BGN 3 billion were invested in modernization with close to zero increase in the combat potential of the armed forces, and many accusations of misbehavior and actions against the MoD and the national interest. Of course, the institutional and legal framework in place in Bulgaria prevents these accusations from being successful either in the prosecution process or in court. The result is that the military lost of about 30 percent of these funds, and of course were left with a totally unbalanced capability structure for the armed forces.

The situation with utilization projects is similar, although an additional concern for utilization is the problem of postponing reserve deployments, which most probably will need some of the equipment and property that are currently being sold without any clear rules to provide integrity of the process. One of the lessons learned from this situation is that in defense reform, downsizing and restructuring are not enough; setting up clear rules for the corresponding processes of procurement and utilization is of great importance, and the integrity of people and processes is of critical importance for success.

\section{Lack of Integration of the Ministry of Defense}

At the end of 1999 and later in 2000-01, one of the required steps for the success of the change management process was effectively stopped-namely, the introduction of amendments to Bulgaria's defense law intended to establish the ministry of defense as a fully integrated governance and management structure. The power of integrity as a principle of change management was shown during the development of the Military Doctrine and Plan 2004, but it was even more important in the implementation phase. Until the end of 2001 and even in early 2002, the system was able to work because of the presence of established integrated bodies, such as the Programming and Integration Councils, the Modernization Council, and directorates in the MoD that were strong 
enough to support their activities. With the degradation of these directorates, a lack of interest from the MoD leadership, and a strong push from the General Staff for separation, the extremely poor decision was made to physically divide the Ministry of Defense and the General Staff into two different buildings. ${ }^{10}$ This step was followed by a total divergence in the agendas of the MoD leadership and the General Staff. In particular, the MoD leadership sought to expand their area of action into non-military issues of supply, social policy, procurement, the medical establishment, etc., working in isolation from the processes of force development and employment in operations being carried out under the General Staff and its politically ambitious chief at this time.

The result was of course a political career for the Chief of the General Staff on one hand, and the marginalization of the armed services in comparison to the "civilian investment and utilization program" carried out by the Minister of Defense. In addition, missteps were made regarding the arrangement of the counterintelligence and judicial system for the defense sector that contributed to higher levels of non-transparency, non-accountability, and a lack of integrity in the process of defense management. This situation was exacerbated after Bulgaria's integration into NATO and with the last coalition government, because issues related to defense and NATO were given very low priority on the political agenda. Rather, much greater emphasis was placed on the prospect of EU membership, with its firm requirements (and the expected funds of approximately EUR 13 billion). And this effect was magnified by pressure from some EU countries on Bulgaria to finalize some misguided procurement projects, which worsened the situation. So a commitment to building integrity is of great importance both in the administration of new member states, and on the side of private businesses and current NATO and EU member governments as well, when it comes to dealing with procurement contracts in new member states.

\section{Iraq Crisis of 2003: Problems with Operational Military Integrity}

When it comes to operational issues, the lack of integrity on the professional level among the military leadership is very dangerous - in fact, it could directly lead to human losses. This was the case in Bulgaria during the early phases of the Iraq Crisis. The then Chief of the General Staff (currently the chief of the political cabinet of the President) tried to block the government's decision to prepare and send troops to Iraq; as a result, when the decision was made, the forces were unprepared for the deployment. This situation was then used to justify extraordinary procurement measures that carried a high risk of corruption and resulted in the acquisition of very low-quality equipment. Subsequently, this lack of integrity and coordination led not only to a series of wrong decisions regarding procurement and force generation (including the selection of personnel), but to some operational errors as well. These poor procurement decisions combined with serious failures in operational command and control provoked special measures being put in place to prevent analysis and the gathering of lessons learned from this operation, rotation after rotation, in order to hide the lack of integrity

10 The U.K. consulting team's simplest recommendation was to unlock the door between the ministry and the General Staff when they were in the same building. 
in the decision-making process. Over time, more and more new problems arose during the deployment of Bulgaria's battalion until it was replaced by a company in a secure area without any real national responsibilities. In this instance, the real problems with Bulgaria's military counterintelligence and judicial system became visible.

Even now, the system for the preparation, deployment, rotation, and redeployment of troops and for gathering lessons learned lacks the level of integrity that is needed for the effective use of forces. Improvements occurred when the Chief of the General Staff was replaced and with the establishment of a Joint Operations Command, but the negative effects of operational processes that were both highly opaque and lacking in integrity have weakened the country. The solution for this problem is rooted in good civil-military relations, parliamentary control over the military, and strong political and professional leadership, based on a high level of collaboration in decision making and real personal integrity.

\section{Elimination of Conscription since 2007: Problems with Military Integrity in Transformation}

The other aspect of the lack of sufficient concerted professional effort within the military to demonstrate integrity as a value and to provide informed support for political decisions is connected with the elimination of conscription. Instead of recognizing the problem and conducting an effective analysis and planning process, the decision was simply postponed repeatedly, until it became significant enough that it took on dimensions that were outside the area of expertise of military professionals. Rather, the problem became sufficiently acute that it became an issue of debate in the wider society and in high political circles, and ultimately the decision to eliminate military conscription was made without the involvement of any military experts. Even after this decision, the lack of integration between the military and the political leadership of the Ministry of Defense led to series of poor decisions about force structure. ${ }^{11}$ In addition, the lack of integrity could be seen in the area of mobilization planning, particularly in the development of the reserve forces that are urgently required after the accelerated downsizing and professionalization of the active forces.

If the proper operational analysis is made, it will be possible to develop genuinely sound options for the force structures of both the active and reserve forces, with an optimal distribution in different garrisons through the country, a redistribution of the available equipment, and optimal planning for both new procurements and the utilization of excess equipment and property. Resistance to implementing good practices and to making the process more transparent (with the involvement of Parliament to set clear rules and a financial framework) is leading to an environment with a very high risk of corruption.

11 These decisions involved reducing the number of personnel in tactical units, where there is a lack of professional soldiers, but keeping very large HQs and support units. The decision was also made to keep a large number of vertical levels in the command and control chain, in order to preserve positions for officers and NCOs while not having enough enlisted soldiers. 


\section{Critical Role of Integrity as a Concept in Change Management and Good Governance of Defense}

A project named SECRES, which was conducted in 2008 to cover the period from 1999 to 2008, was focused on studying the influence of security-related research on decision making in Bulgaria's security sector. ${ }^{12}$ The hypothesis behind the project was that good decisions are based on research results and are examples of a high level of collaboration, which subsequently leads to improved chances for successful implementation, and thus to the achievement of results that meet with a high level of public support. Practically all the successful decisions made in the 1999-2008 period were the result of a transparent, research-supported process with high levels of accountability and civil society involvement as well as openness to input from NATO allies. In contrast, most of the failures from this era are connected with non-transparent decisions that intended to avoid accountability and did not rely on any research to support the development of options for analysis and selection.

In addition, all the "positive results" were achieved by using an institutional approach, and contributed to building institutional capacity, optimal processes, and integrity in the defense establishment. Most of the "negative results" were due to the tendency to avoid institutions and established processes of decision making and accountability, which as a result corrupted the integrity of the people and institutions involved.

This analysis leads to the following conclusions and recommendations:

- Successful change management requires clear leadership with vision, will, value-based faith, and responsibility

- Transparency and accountability combine to form an environment that will prevent mistakes and the abuse of power in transition periods

- Involvement of civil society in the process of transformational change is essential, and could increase the level of collaboration in the process

- Professional integrity of the military is a necessary basis for making key decisions and their successful implementation

- Legislative amendments are crucial to jump-starting change in the area of integrity, but parliamentary control and a robust judicial system are of critical importance to keep this process going on successfully

- Institutional and process development is a requirement for integrity in the long term.

- NATO and the EU have to insist on the issue of integrity as a value and concept more seriously and at earlier stages of the membership process.

12 Velizar Shalamanov, ed., Security Research and Change Management in the Security Sector (The Bulgarian Example in the Period 1999-2008), Change Management Series (Sofia: Institute for Parallel Processing, G. C. Marshall Association - Bulgaria, 2008) (in Bulgarian). 


\section{Conceptual answers to the Challenges}

\begin{tabular}{|l|l|l|}
\hline No & \multicolumn{1}{|c|}{ Challenge } & \multicolumn{1}{c|}{ Concept } \\
\hline 1 & $\begin{array}{l}\text { Security and Development } \\
\text { Architecture }\end{array}$ & $\begin{array}{l}\text { NATO and EU Enlargement and } \\
\text { Improvement }\end{array}$ \\
\hline 2 & Security Sector Architecture & $\begin{array}{l}\text { Integrated Security Sector as Strategy } \\
\text { Focused Organization }\end{array}$ \\
\hline 3 & $\begin{array}{l}\text { Environment for the development of } \\
\text { the Security Sector }\end{array}$ & $\begin{array}{l}\text { Change Management for Good, Small } \\
\text { and Smart Government with Integrity }\end{array}$ \\
\hline 4 & Operations & $\begin{array}{l}\text { Integrated Crisis Management through } \\
\text { Effects-Based Operations }\end{array}$ \\
\hline 5 & Capabilities & $\begin{array}{l}\text { Capability Based, Scenario Driven } \\
\text { Planning / Programming }\end{array}$ \\
\hline 6 & $\begin{array}{l}\text { Command and Control - } \\
\text { Governance / Management } \\
\text { Integration and Improvement }\end{array}$ & $\begin{array}{l}\text { Architectural Approach, project } \\
\text { management, quality assurance }\end{array}$ \\
\hline 7 & Resource management & $\begin{array}{l}\text { PPBS ... Balanced Score cards } \\
\text { approach }\end{array}$ \\
\hline
\end{tabular}

Concept Development - OA

CAX - Experimentation

Figure 5: Concepts to Address Challenges in the Security Sector Change Management Process.

The change management process in the security sector faces many challenges, including those areas listed in Figure 5:

1. Security and development architecture

2. Security sector architecture

3. Environment for the development of the security sector

4. Operations

5. Capabilities

6. Command and control: governance, management, integration, and improvement

7. Resource management.

Clear concepts are required in order to cope with these challenges, followed by effective implementation, which should include experimentation, training, and steps for the permanent improvement of the processes. Following the order of the challenges outlined above, some of the concepts that have been adopted in Bulgaria to address them are:

1. NATO and EU enlargement and improvement

2. Integrated security sector as a strategy-focused organization 
3. Change management for good, small, and smart government

4. Integrated crisis management through effect-based operations

5. Capability-based, scenario-driven planning and programming

6. An architectural approach to project management and quality assurance

7. PPBS and a balanced score-card approach

These concepts could be integrated into the Strategic Map of the Integrated Security Sector (Figure 6) and translated later in Balanced Score Cards (Figure 7) for the strategic management of the defense sector.

The mission of the integrated security sector could be discussed under different rubrics, such as how best to provide security for the citizens, communities, and state as well as provide support for social and economic development. In order to serve to this mission, the main goal of the activities of the security sector are expected to be success in current operations, leadership in the organizational and technological spheres (in order to be better prepared for the future and effective NATO/EU integration), as well as international security cooperation to shape the security environment.

Integrated Security Sector as Strategy Focused Organization Mission: Security for the citizens, communities, state and support for social and economic development

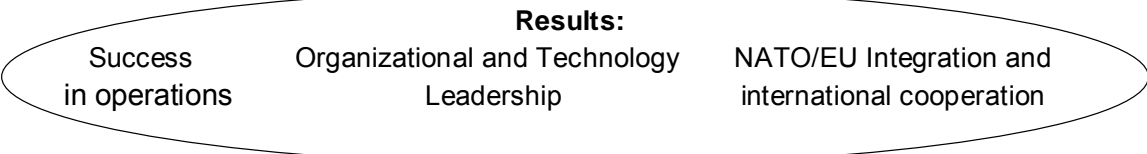

Key competencies: defense, expeditionary capabilities, air security, maritime security, border security, public order, fighting crime, incident/emergency management, intelligence, security policy

Internal Processes:
Leadership
Good Governance
Change management capacity
Analytical Support
Integrity

Knowledge and Development:

People: Values Training Recreation Career Medical Support Housing Social Integration Research \& Knowledge Industrial

Reputation Public \& Political

Budget

infrastructure base support

Figure 6: Strategic Framework for the Integrated Security Sector. 
An integrated security sector is expected to maintain its core competencies in territorial defense, expeditionary capabilities, air security, maritime security, border security, public order, crisis management, fighting crime, intelligence, security policy development and implementation, and support to civilian authorities in order to be able to fulfill the tasks mentioned above. As for the improvement of internal processes, the level of integrity is the key indicator, supported by leadership, models of good governance, change management, and analytical support capacities. The foundation for the implementation of such a strategy is the investment in people, a research infrastructure, the nation's industrial base, and visible public support at high levels (along with the provision of an adequate budget).

Such a strategic map is generic for new or aspiring NATO members, as well as for other active partners who aim to be integral parts of the Euroatlantic community of the shared values of liberty, democracy and security. Serious analysis is required in the area of security sector architecture and the political, social, and economic realities in each country in order to define the precise strategic map that will address all the relevant institutions inside that country's security sector.

Implementation of the strategic map requires management based on balanced scorecards in four different spaces. An example of such an instrument is given in Figure 7. Again, we could claim that building integrity is a critical factor for internal processes in the security sector.

Balanced Score Cards for the Integrated Security Sector

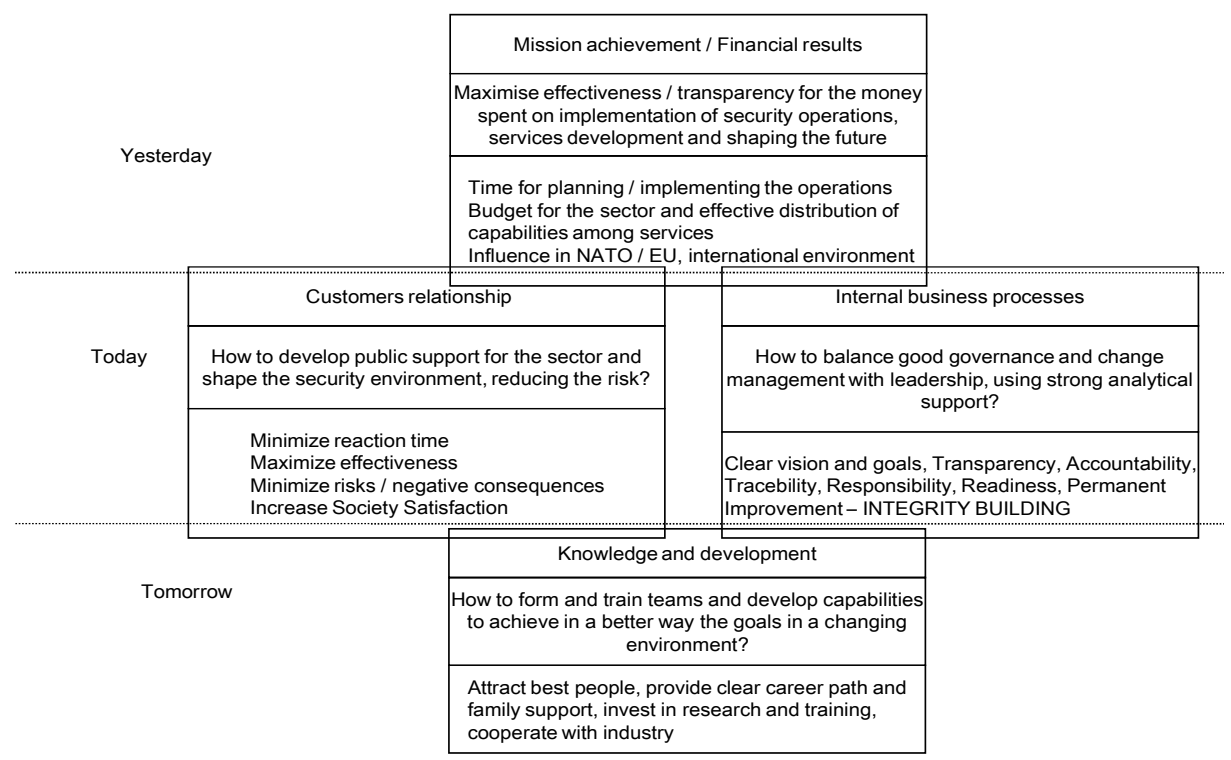

Figure 7: Balanced Score-cards Example for the Integrated Security Sector. 
We could define a set of strategic initiatives to be implemented in the framework of the strategic map and managed through the balanced score-card system:

1. Sliced integrated security: national, crisis management, and civil security (the last with responsibilities and capacity on the local level)

2. Reserve forces and volunteers' involvement; public-private partnership in security

3. Combined joint common operating picture and intelligence sharing

4. Integrated C4ISR for all operations and all services in the integrated security sector and in the NATO/EU context

5. Joint regional procurement for expensive high-tech platforms

6. Downsizing and outsourcing of nonessential security functions

7. Quality of life investments for security sector personnel

8. Leadership in innovation and research; education and training in the security domain

9. Good governance and integration building in the security sector; analytical support for decision making in security.

Using operational analysis, the strategic map frames the set of strategic initiatives in the defense area. An example from the current analysis for Bulgaria is presented in Figure 8 .

MoD Strategic Initiatives 2009-2013

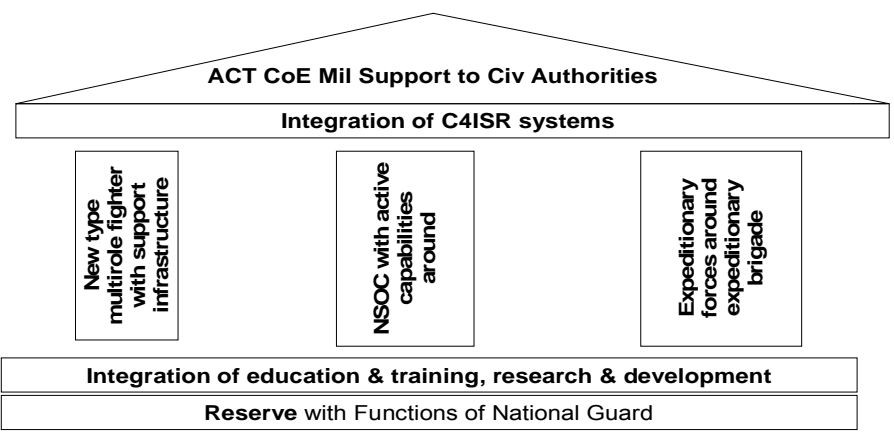

Integrity in Defense means to do right things right way even without push from allies, but for the country and its citizens

Figure 8: Strategic Initiatives for the Bulgarian MoD according to the Analytical Community in the Bulgarian Academy of Science. 


\section{Special role of $O A$ and CAX for Change Management}

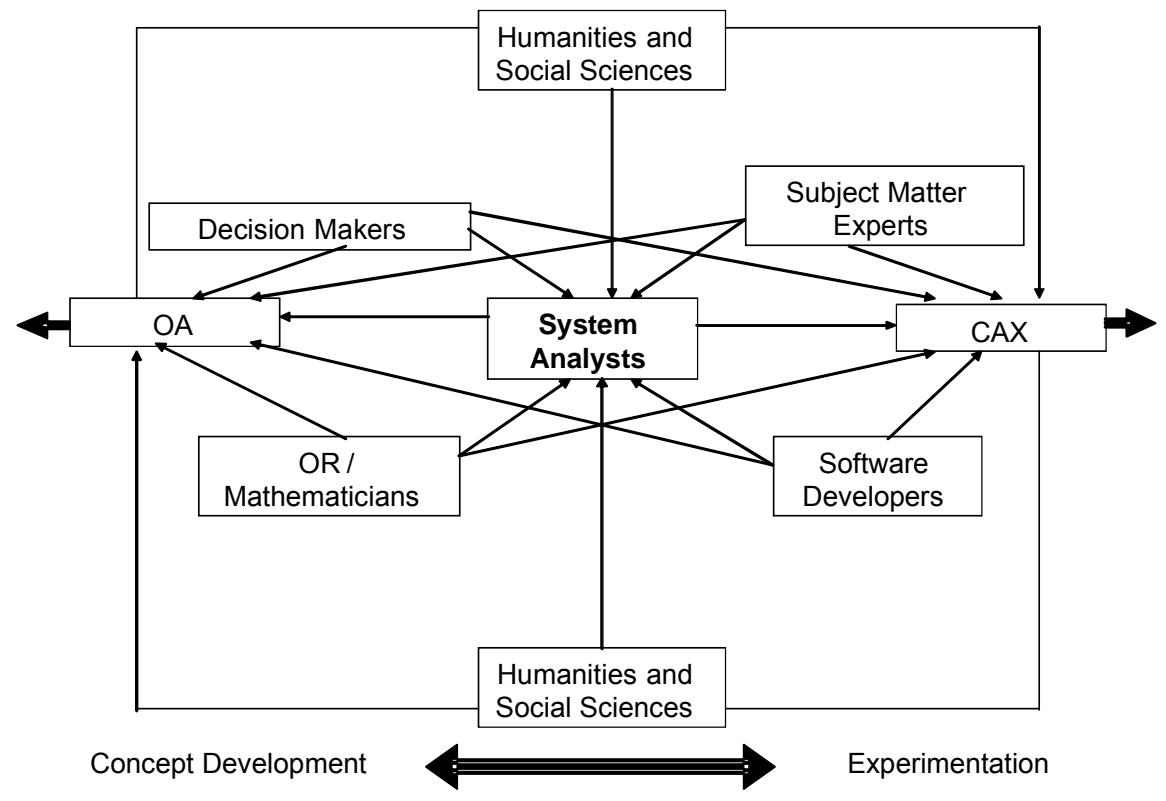

Figure 9: Support of OA and CAX to Concept Development and Experimentation for Change Management.

It was mentioned above that operational analysis (OA) could play a positive role in enabling better decisions; it can also make a contribution to the development of models of good governance. In addition, our studies proved that testing new concepts of alternatives for decisions, or even developing alternatives through computer-assisted exercises (CAX) could significantly improve transparency, effectiveness, and efficiency, and can provide opportunities for measurement and accountability.

Using NATO SfP981149 and NATO SfP982063 projects in Bulgaria to build capacity in OA and CAX in support of security sector transformation showed that it was possible to positively influence the decision-making process. ${ }^{13}$ This approach has to be internalized in the MoD/GS, and after that partly outsourced to the academic sector in order to provide for high-quality analyses. At the same time, this approach could be used as a tool to drive integration between the MoD and other security sector entities, such as the Ministry of the Interior, Ministry of Emergency Management, etc., using the same academic basis for their operational analyses. It could also prove to be of use

${ }^{13}$ Klaus Niemeyer, Velizar Shalamanov, Todor Tagarev, Tsvetomir Tsachev, and Michael Rademaker, Operations Research Support to Force and Operations Planning in the New Security Environment, NATO SfP 981149 Final Report (Sofia: Artgraf, 2008). 
in the future as well, if decisions in the security sector could be based on genuinely integrated joint studies. Including the humanities and social sciences in the loop is of great importance as well, as has been illustrated recently by decisions in the security sector that have been heavily influenced by public perceptions, and whose results are more directly related to the security of the citizens than any time in the past (see Figure 9).

The implementation of a well structured decision-making process that benefits from the use of OA/CAX tools and is open for inspection by independent monitors from civil society and the academic community (as shown in Figure 10) is the only solid foundation for building integrity in defense institutions. One example was the organized monitoring carried out by the Security Sector Reform Coalition in Bulgaria, based on a developed set of criteria for integration in the NATO Readiness Indicator for the country, which provided reports to the Parliament on civil society's assessment of Bulgaria's preparation to join NATO. ${ }^{14}$

\section{Governance Model in Security Sector / Public Sector Good Governance Center:}

Research on Governance Models, Collect and Analyze Best Practices, Independent Monitors (IM)

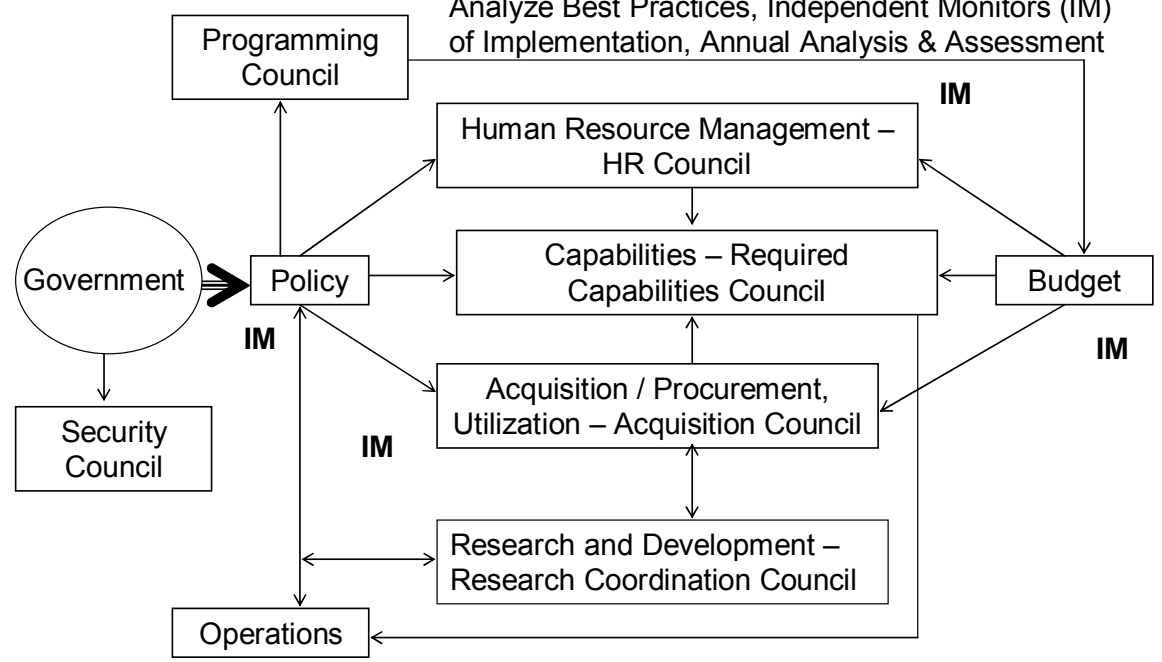

Start National and transition to Regional - SEE, WBSA

Figure 10: Governance Model, based on a Well-Defined Process of Decision Making and Independent Monitoring.

14 Velizar Shalamanov, Lyubomir Ivanov, and Petya Dimitrova, NATO Membership Readiness Indicator (Sofia: George C. Marshall-Bulgaria with the Atlantic Club in Bulgaria, 2001). 


\section{Conclusions: The Role of NATO in Building Integrity for New Member States and Partners}

As a result of not following best practices in governance and management, both in the security sector and other branches of public administration, numerous scandals emerged in Bulgaria in the recent past that led to changes in the government and to the formation of the State National Security Agency in 2008. This agency's key mission is to fight corruption and organized crime at the highest levels of the nation's political and administrative structures.

Even in this environment it is very difficult to achieve support for a comprehensive approach to good governance through the program of integrity building for the security sector or public administration at large. This resistance is a clear indicator of how important this program is for change, and of how difficult it will be to implement without strong public support and external pressure. For example, the current special law on conflicts of interest was proposed by the government under the pressure from the EU; when such a law was proposed by the former Prime Minister Mr. Philip Dimitrov, it met with harsh opposition, and was rejected at least five times by the same Parliament.

In order to be successful in enhancing integrity in the defense establishment, it is important to develop a clear framework in support of the process (an example is show in Figure 11). The Ministry of Defense has to define very clearly its contribution to security, and to have it publicly stated in the National Security Strategy, with further development of the details about the parameters of the capable forces, industry, and research as well as the guarantees for the internal security of the institution. Based on these developments, democratic control could contribute to public support, which is the real foundation of the defense establishment.

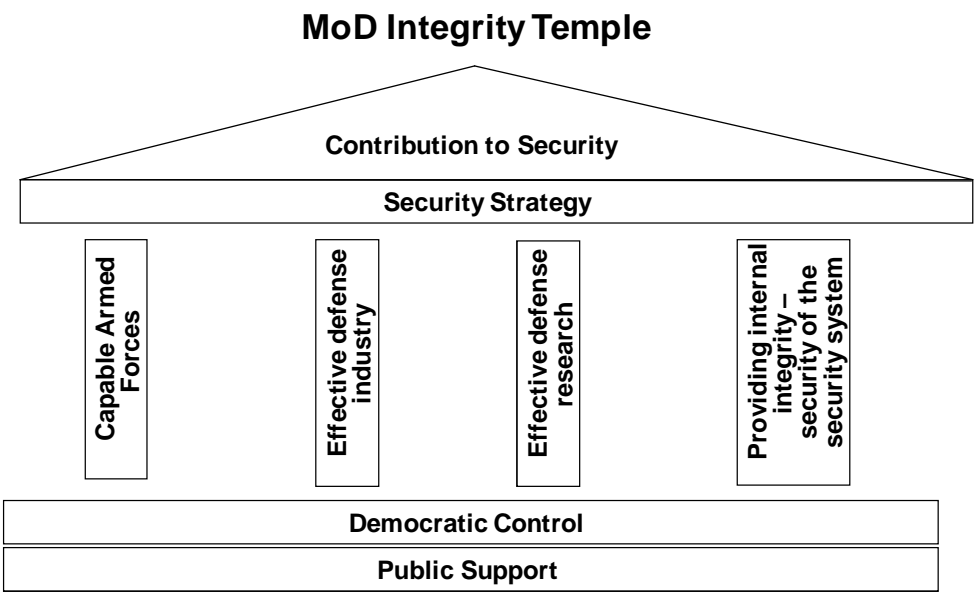

Figure 11: Framework in Support of Building Integrity for the MoD. 
The role of civil society and non-governmental organizations is also extremely important in the process of building defense institutions for effective defense policy. ${ }^{15}$

Some conclusions drawn from the review of the role of building integrity in defense reform process could be listed as follows:

1. SDR efforts supported by NATO and allied countries are building the base for change and integrity

2. PARP and the Defense Planning Questionnaire (DPQ) are effective tools to maintain integrity in the center of defense development

3. The Partnership Action Plan on Defense Institution Building (PAP-DIB) could be very instrumental in supporting the foundation of integrity

4. NATO-led training, education, and engagement with civil society, parliaments, and judicial branches as well as with defense industry is crucial to ensure the stability of building integrity in support of successful change management

5. Measurement and assessment tools are needed to gain an adequate understanding of the situation and find directions for improvement

6. Building integrity in the defense establishment must lead to the extension of this experience to other areas of public administration in order to be successful

7. Use of OA and CAX as tools to improve the quality of governance and management is a powerful instrument to support integrity building for instrumentalizing decision making in the change management process.

In conclusion, it is important to stress the role of the integrity pillar within defense reform, and the contribution of different instruments of defense reform (e.g., SDR) to build more effective institutions. At the same time, however, we have to recognize that in order to succeed we need the combination of internal motivation and capabilities mixed with external support and encouragement, and that often this effort is required not only in the defense establishment, but in the larger political context as well as in business circles (especially among Western defense contractors).

Building integrity could be compared to the efforts of process improvement in business organizations using certain maturity models. For public institutions in free nations, integrity is the key criterion for maturity, and is required if these institutions are to be able to work in the public interest, in a transparent and accountable way.

In order to support the processes of building both integrity and institutions in the defense sector, there are sets of tools already available within NATO and the Partnership for Peace. Training and co-learning among practitioners are both effective tools to use in such an approach, but the time may have come to address the issue more directly and in a more comprehensive way.

15 Velizar Shalamanov, "Defence Management and Civil Society Interaction and Co-Operation," in Defence Institution Building: A Sourcebook in Support of the Partnership Action Plan (PAP-DIB), ed. Willem van Ekelen and Philipp Fluri (Geneva \& Vienna: DCAF/ Austrian Study Group Information, September 2006), 435-66. 


\section{Bibliography}

Bulgaria's Way: A Book for the Partners - Our Vision, Our Will, Our Faith. Sofia: Ministry of Defense, 1999.

Monitor, I\&S. "Operations Research Support to Force and Operations Planning in the New Security Environment." Information \& Security: An International Journal 16 (2005): 130-131.

Niemeyer, Klaus, Velizar Shalamanov, and Todor Tagarev. "Institutionalizing Operations Analysis for Security and Defense in Bulgaria." Connections: The Quarterly Journal 7, no. 2 (2008): 45-53.

Ratchev, Valeri, Velizar Shalamanov, and Todor Tagarev. "Reshaping Bulgarian Armed Forces for the 21st Century." In Bulgaria for NATO 2002. Sofia: Institute for Regional and International Studies, 2002.

Shalamanov, Velizar, and Todor Tagarev. Reengineering Defense Planning in Bulgaria In Research Report. Sofia: Institute for International and Security Studies, 1998.

Shalamanov, Velizar, Lyubomir Ivanov, and Petya Dimitrova. NATO Membership Readiness Indicator. Sofia: George C. Marshall-Bulgaria with the Atlantic Club in Bulgaria, 2001.

Shalamanov, Velizar. "Activities and Problems in the Bulgarian Ministry of Defence Concerning NATO Enlargement." In International Workshop on Transparency of Defence Resource's Planning and Budgeting: National and Euroatlantic Dimensions, 92102. Sofia: University Publishing Stopanstvo, 2002.

Shalamanov, Velizar. "Civil Security and Crisis Management: The Concept Development and Experimentation Process in Bulgaria (the Role of the US, NATO, and the EU in SEE)." In The Fight Against Terrorism and Crisis Management in the Western Balkans, 147-164. Amsterdam: IOS Press, 2008.

Shalamanov, Velizar. "Civil-Military and Interagency Cooperation in the Security Sector in Bulgaria." In Security Sector Reform - Does It Work?: Problems of CivilMilitary and Interagency Cooperation in the Security Sector, 79-114. Geneva: DCAFGCMA, 2003.

Shalamanov, Velizar. "Defence Management and Civil Society Interaction and CoOperation." In Defence Institution Building: A Sourcebook in Support of the Partnership Action Plan (PAP-DIB), 435-66. Geneva \& Vienna: DCAF/ Austrian Study Group Information, 2006.

Shalamanov, Velizar. "Lessons of Transition in Bulgarian Security and Defense." Information \& Security: An International Journal 5 (2000): 9-19.

Shalamanov, Velizar. "Priorities of Bulgarian Defense Policy and Planning." Security Policy 2 (1999): 3-21.

Shalamanov, Velizar. Security Research and Change Management in the Security Sector (The Bulgarian Example in the Period 1999-2008) In Change Management Series. Sofia: Institute for Parallel Processing, G. C. Marshall Association - Bulgaria, 2008. 


\section{THE QUARTERLY JOURNAL}

Tagarev, Todor. "Introduction to Program-based Defense Resource Management." Connections: The Quarterly Journal 5, no. 1 (2006): 55-69. 